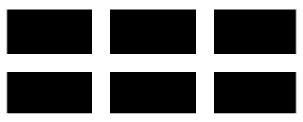

THE WILLIAM DAVIDSON INSTITUTE

AT THE UNIVERSITY OF MICHIGAN BUSINESS SCHOOL

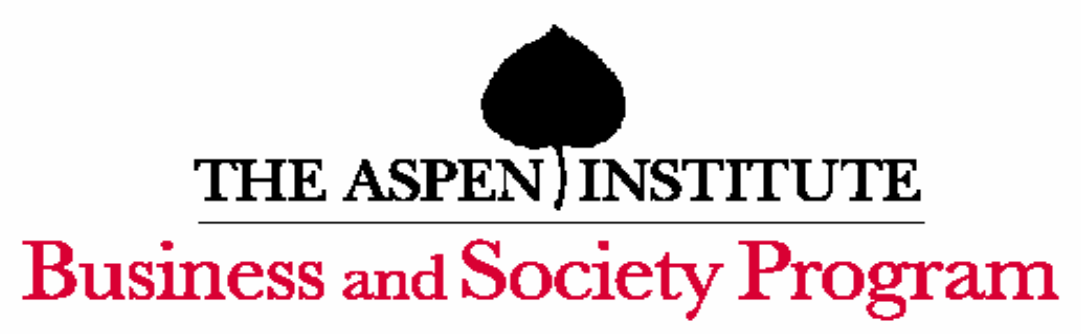

Institutional Change and Firm Creation in East-Central Europe: An Embedded Politics Approach

\author{
By: Gerald A. McDermott
}

William Davidson Institute Working Paper Number 590

June 2003 


\title{
Institutional Change and Firm Creation in East-Central Europe: An Embedded Politics Approach^^${ }^{\wedge}$
}

\author{
Gerald A. McDermott* \\ Assistant Professor \\ Management Department \\ The Wharton School \\ University of Pennsylvania \\ 2000 Steinberg Hall-Dietrich Hall \\ Philadelphia, PA 19104 \\ Tel: (215) 573-4923 \\ Email: mcdermott@wharton.upenn.edu
}

Research Fellow

IAE, Universidad Austral

Buenos Aires, Argentina

February 2003

Paper presented at the WDI-Aspen Institute ISIP Conference, "Trust, Institutions, and Globalization,” Aspen, Colorado, March 14-16, 2003.

^ I am grateful for the comments on earlier versions from Richard Deeg, David Dornisch, Grzegorz Ekiert, Anna Grzymala-Busse, Mauro Guillen, Vit Henisz, Yoshiko Herrera, Chip Hunter, Wade Jacoby, Steve Kobrin, Bruce Kogut, Tony Levitas, Katharina Pistor, Akos RonaTas, Andrew Spicer, Rudy Sil, Sid Winter, David Woodruff, and Rick Woodward. All errors and omissions are my own.

* McDermott's current research analyzes the relationship between participatory forms of governance and economic performance in Latin America and East-Central Europe. His publications include articles in Industrial and Corporate Change and Academy of Management Review, as well as his new book, Embedded Politics: Industrial Networks and Institutional Change in Post-Communism (University of Michigan Press). See also his website: http://wwwmanagement.wharton.upenn.edu/mcdermott/.

Keywords: Institutions, governance, restructuring, post communism, transitions 


\title{
Institutional Change and Firm Creation in East-Central Europe: An Embedded Politics Approach
}

\begin{abstract}
A central debate about the transformation of post-communists countries is how the process of institution building impacts firm restructuring and creation. This debate has largely been dominated by approaches that emphasize either the depoliticization of institutional designs or the determining impact of pre-existing social structures. These views, however, have serious problems explaining one of the key comparative developments in East-Central Europe - the strong economic growth in Poland and the demise of the Czech Republic in the 1990s. This paper explains these differences by offering an alternative, embedded politics approach that views firm and institutional creation as intertwined experiments. Czech attempts to implant a depoliticized model of reform impeded the necessary reorganization of socio-political networks, in which firms are embedded. Poland facilitated institutional experiments not only in the ways it promoted negotiated solutions to restructuring, but also in the ways it empowered sub-national governments. The study utilizes data on manufacturing networks, privatization, bankruptcy, and regional government reforms collected over the past six years.
\end{abstract}


A central debate about the transformation of post-communist countries is how the process of institutional change impacts firm restructuring and creation. Two literatures on economic development have largely dominated this debate. The depoliticization approach, often found in economistic and developmental statist views, understands transformation as discontinuous change. A coherent, autonomous state imposes a new "right" set of rules and incentives on a tabula rasa of atomized firms and banks. Sociological approaches tend to emphasize the continuity of past social structures determining firm strategy and policy choices.

The problem is that neither of these approaches offers a convincing explanation for a key development during the 1990s in East-Central Europe: Poland's strong economic growth and the Czech Republic's stagnation. Indeed, advocates of both approaches viewed the Czech case as a relative success and as a major source of supporting evidence.

This essay explains the relative Czech failures and Polish successes in the restructuring and creation of manufacturing firms by offering an alternative embedded politics approach that attempts to connect productive outcomes to the organization of policy-making power. Industrial adaptation is a product of institutional experiments, which in turn are shaped by the relative concentration and diffusion of public power.

In this view, firm and public actors created distinct socio-political networks to obtain resources and to protect themselves during communism from the uncertainties of shortage economies. During the transformation period, firms remain embedded in manufacturing networks but, in contrast to the dominant approaches, are unable to reorganize assets on their own. While vital economic interdependencies constrain firm discretion and assertion of ownership rights, high uncertainty undermines contractual solutions to conflicts over restructuring strategies and asset control. Historical social bonds between firms also fail to mediate conflicts. Past norms of reciprocity depended in part on the political and material 
resources certain firms gained from alliances with regional political actors who now have essentially disappeared. Firm restructuring and creation depend rather on how government policies enable interconnected firm level actors to negotiate over time their overlapping property rights and the reorganization of assets. As with asset workout and risk sharing regimes typical of advanced industrialized countries, these processes demand that public actors mediate conflicts, provide partial financial relief, and monitor the new use of assets by private parties.

This paper argues that the Czech government impeded the development of any such role for public actors because of its attempts to maintain a powerful, insulated state and draw a sharp boundary between state and society. In contrast, Polish approaches to privatization, bank restructuring, and even support for new firms facilitated negotiated restructuring and risk sharing because of the way public power was unpacked. A variety of national and sub-national government actors were empowered both to explore new institutional roles to support firm restructuring and creation and to monitor one another.

Section I critiques the two dominant approaches and reviews the main arguments of an embedded politics approach in light of the stark differences between Polish and Czech policies and their manufacturing outcomes. Sections II and III then explore these arguments empirically. Using primary network data from the Czech Republic, I am able to define the political conditions and policy choices that would impede or aid the reorganization manufacturing networks. ${ }^{1}$ I then compare these conditions and choices between Poland and the Czech Republic. (Ragin 1987)

\section{Explaining the Divergence in Growth and Firm Creation}

By the end of the 1990s Poland was the economic leader in the region, especially over the Czech Republic. Between 1989 and 1998, real GDP grew by $17 \%$ in Poland but declined by $4 \%$ in the Czech Republic, a difference largely due to relative performance in the restructuring and creation of manufacturing firms. (Kawalec 1999, Blaszczyk and Woodward 1999, Klich and Lipiec 2000) 
Not only did industrial labor productivity increase by three times more in Poland than in the Czech Republic, but also, as can be seen in Figure 1 and Table 1, the Poles strongly outpaced the Czechs in terms of growth in industrial output and the creation of manufacturing firms, indicated by the growth in employment in small- and medium size firms (SMEs). How can one explain the stark contrast in the industrial restructuring and firm creation?

One explanation comes from depoliticization advocates, who view transformation as a moment of epochal change from communism to capitalism. Depoliticization is the ability of the state to eschew negotiations with economic and social actors about the initial institutional designs and their subsequent revisions. ${ }^{2}$ It is achieved when the central state constructs a powerful, insulated "change team" to impose rapidly a new set of economic rules (ideally those of free trade and private property rights) that directly guide atomized firms and individuals toward efficient resolution of restructuring conflicts. Rapid, mass privatization and market liberalization allows various claimants to assets strike "efficient bargains" - i.e., through enforceable contracts, liquidations, and buyouts - so that resources can be quickly directed to fruitful investments and new firms. (Boycko et al. 1995, World Bank 1996)

While one cannot deny the importance of private property rights and market forces, this approach suffers from explanatory problems. First and foremost, by the mid-1990s both independent scholars and the multilaterals viewed the Czech Republic as the crowning success of the depoliticization approach, with Poland as the laggard. (World Bank 1996, Camdessus 1994, Frydman and Rapaczinski 1994, Boycko et al. 1995, EBRD 1995) Orthodox communist policies had left the Czech Republic with a stable macro-economy, low foreign debt, poorly organized social and political groups, and a central government with virtually complete legal control of assets. A coalition led by Vaclav Klaus used these conditions to construct a strong policy apparatus that cut itself off from potential "rent-seekers," such as parliament and special interest 
groups. It weakened workers councils, dissolved regional councils (blocking their reestablishment until 2000), and reduced the powers and resources of fragmented local governments. The government liberalized trade and most prices and enacted conservative monetary and fiscal policies. It quickly implemented strict banking regulations, a rule-based recapitalization of banks, a bankruptcy law based on liquidation of defaulting debtors, and the privatization over 1,800 firms and four of the five main banks in less than four years through its now famous voucher method.

In contrast, although Poland implemented disciplined fiscal and monetary policies, it delayed firm and bank privatization. (World Bank 1996, EBRD 1995, Frydman and Rapaczynski 1994) Policies of partial economic and political liberalization, particularly in the $1980 \mathrm{~s}$, left the country with large fiscal deficits and foreign debts and relatively well-organized social groups and competing political factions, notably in Solidarity and the farmer associations. While different political groups competed for policy control, such stakeholders as workers councils, managers and local governments intervened in and often exercised veto rights over the privatization of assets. Privatization, in turn, slowed and pursued multiple goals, such as maximizing sales revenues and maintaining employment, rather than simply focusing on the rapid delineation of private ownership rights. For instance, the Polish version of voucher privatization was not implemented until 1995-96, concerned only 512 firms (10\% of industry and construction sales), and allowed for the state to maintain $25 \%$ ownership. Privatization of the major Polish banks did not begin in earnest until the late 1990s. (Jarosz 1999, Blaszczyk and Woodward 1999, Tang et. al. 2000)

As shown in Table 2, the immediate results of these contrasting approaches fortified the view that the Czechs were the leaders of depoliticization. By 1995 the Czechs raced ahead of Poland in private sector control of industry and banking and in the provision of bank credit to 
private firms. Moreover, while the Czech Republic achieved investment grade status and its banks exceeded the Basle banking capital adequacy ratios by 1994, studies showed that Czech start-ups and small and medium sized enterprises (SMEs) had relatively greater access to bank credit than their Polish counterparts. (EBRD 1995; Bratkowski et al. 1999)

However, as both independent scholars and the World Bank have shown, the two proposed motors for firm restructuring and firm creation - the capital market and bank finance collapsed in the Czech Republic by 1998. (World Bank 1999, Nellis 1999, Coffee 1999) Mass privatization bred a combination of mismanagement by the large investment funds with crossholdings in the main Czech banks and speculative, insider trader schemes by new Czech entrepreneurs. In the meantime, the Czech use of bankruptcy mainly as punishment and liquidation of delinquent debtors led the banks to view restructuring as too risky. While nonperforming loans would grow steadily in the 1990 s from $19 \%$ to $30 \%$ of total loans, they would decline from 30\% to 10\% in Polish banks. (Tang et al. 2000) By 1999, as creditors made little progress in voluntary workouts, the Czech government was forced to restructure and re-privatize the banks and seven of the largest manufacturing firms. Table 3 shows the extent to which the Poles outpaced the Czechs in the 1990s in terms of several key micro- and macro-economic indicators.

Attempts to save the depoliticization approach try to explain the Czech demise by referring to problems in securities laws and soft budget constraints (Johnson and Shleifer 1999, EBRD 1999) and the rise of Polish SMEs by referring to secure property rights (Johnson and Loveman 1995, Johnson et al. 2000). ${ }^{3}$ Yet such arguments not only offer little insight into the creation of financial regulatory institutions but also ignore the fact that into the late 1990s the Polish national and sub-national governments owned and restructured most large firms and banks, leased firms to employees, and created regional development agencies. In turn, the 
difference in productive outcomes may be less about rapid state withdrawal and privatization per se and more about how governments developed effective oversight capabilities as well as institutional mechanisms to facilitate the reorganization of assets and liabilities.

The dominant competing explanation about restructuring and firm creation during transformation comes from economic sociology. This approach emphasizes the continuity of social structures, namely how the structure, density, and strength of past inter-firm and professional networks help gauge the ability of firms to cooperate, access new information and resources, maintain market positions, and innovate. ${ }^{4}$

The work of David Stark is the most prominent here. (Stark 1986, 1996; Stark and Bruszt 1998) Stark argued that even after the fall of the party-state, firms remained embedded in constellations of horizontal and vertical socio-economic relationships that grew out of improvised responses to the uncertainties of the shortage environment during communism. The reproduction of network ties provided constituent firms with reliable channels of resources and information as well as norms of reciprocity to help "recombine" assets in a variety of ways. Network analysis helped scholars compare distinctive patterns of economic organization across countries as well as over time.

However, Stark over determines the ability of economic actors to preserve their network relations, particularly in ways that promote restructuring, rather than, corruption or poor management. For instance, Stark argues that the Czech case is a prime example where past informal network relationships were reproduced into sound economic governance structures. His evidence is the emergence of the complex interlocking ownership and financial links among the main Czech banks, their investment funds, and their overlapping portfolios of privatized state firms. The decline of Czech restructuring and capital markets would rather suggest that the productive qualities of inherited networks depend on factors beyond socio-economic relations 
and, in turn, can be significantly shaped, positively and negatively, by a country's approach to institutional change.

My alternative, embedded politics approach attempts to identify factors of both continuity and change in firm behavior by understanding how the political-institutional architecture of a country shapes the evolution in the structure and cohesion of industrial networks. Past economic and social ties can initially shape and constrain firm strategy. But the ability of interdependent firms to reorganize these ties and production depends on how countries change the structure of political power to support policy choices about privatization and restructuring. (Johnson 2001)

Building on recent research in a variety of East European countries, I argue that upon entering the transformation period manufacturing firms were embedded in socio-political networks, which included regional bank and party council officials. ${ }^{5}$ For instance, my own research of Czechoslovak planning in the 1970-80s showed that mid-level institutions, such as industrial associations (VHJs) and regional councils, took on greater decision-making rights over, respectively, production and social-welfare services. (Hayri and McDermott 1998 and McDermott 2002) Within VHJs, firms and plants developed broad production scopes and tight production and financial interdependencies to limit the uncertainties of shortage. At the same time, managers formed alliances with local state bank branches and party councils to gain privileges from the state center and create informal channels of coordination. These alliances provided certain member firms with political and material resources and thus intra-network bargaining power that solidified the governance of the network.

This view ties restructuring and the redefinition of property rights into a collective action problem. Because of mutual subcontracting linkages or joint use of R\&D plants, part of the value of a firm accrues from other firms in a network, and thus firms have limited individual discretion about how to change production. As these firms pursue competing restructuring 
strategies, conflicts however emerge over production priorities, the use and control of assets, and the division of risk. But resolution is not immediately forthcoming. The lack of information about the returns of a production strategy can be too great for a firm to give credible contractual guarantees to subcontractor or to a bank to finance the investment or a buyout. Past informal rules of reciprocity lose value since they were derived in part from previous public actors who may no longer be available. For instance, in the Czech Republic, while critical suppliers refused to change production for key customers, the main banks found it too risky to lead restructuring, despite their strong financial linkages with industrial firms. At the same time, the centralization of policy making power that virtually eliminated regional and local councils also cut intranetwork bargaining power for certain firms. In turn, the force of past norms was diluted.

Solutions to these collective action problems would appear possible to the extent that the inter-linked actors can purse their different restructuring experiments while gradually redefining property rights and building confidence that each will take into account the interest of the other. Such processes are often found in institutions of advanced industrialized countries that support asset reorganization and risk sharing. (Cui 1995, Moss 1996, Berk 1994) The common emphasis is to aid stakeholders to risky ventures - e.g., firms, workers, and creditors - in simultaneously improving mutual monitoring and employing assets for new uses. To do so, these state-backed institutions provide limited financial breathing room, incentives for a continued flow of resources, and rules for frequent, disciplined negotiations among stakeholders to exchange property rights and information.

Two political-institutional conditions, in turn, arise to foster firm restructuring and creation. First, to the extent that transformation policies promote institutional mechanisms that help parties to assets negotiate their overlapping claims while sharing risk and information, then these actors are more likely to extend their time horizons, reorganize network ties, invest, and 
build new firms. For instance, privatization may be less about immediate delineation of exclusive ownership and more about how stakeholders and even new outside interests to firms are able to implement new production experiments while gradually exchanging control rights to different pieces of the assets. Bank restructuring may be less about rapid privatization, recapitalization, and liquidation of delinquent debtors and more about how banks and their major clients learn to restructure assets and redefine the terms of their relationships. In both cases certain stakeholders are delegated different restructuring responsibilities but with limited control rights. At the same time they submit to rules of frequent joint deliberations that demand continuous information exchange and mutual evaluation of actions taken. (Sabel 1994)

Second, the structure of political power can impede or foster the ability of government to become a needed third party in promoting and supervising such activities. The principles of depoliticization would tend to undermine these processes since the emphasis on the centralization and insulation of political power would stifle the ability of public actors to initiate and monitor solutions to restructuring conflicts. On the other hand, public actors at both the national and sub-national level are more likely to experiment with their new institutional roles to the extent that they have the requisite discretion and resources. Recent research on the development of institutions that promote investment and risk sharing, be they for workouts, new firms, or new technologies, shows that the principles of delegation and deliberation are also central to institutional experiments. (Sabel 1994, 1996a,b; Cohen and Sabel 1997) By delegating specific restructuring or privatization responsibilities to relevant public and private actors, the central government obtains agents with superior information to execute policies. Frequent deliberations over the goals and progress of a policy between, say, local government representatives or bank supervisors and the relevant managers forces each to reveal new information, compare results, and improve mutual monitoring over the uses of resources. 
The emphasis here is on how the organization of political power helps or hinders banks and firms govern the reorganization of manufacturing networks. As the following section argues, Czech's government's attempt to create and maintain an autonomous, powerful central policy-making apparatus impeded the ability of interdependent firm and bank actors to generate stable collective solutions for asset reorganization. Section 3 then argues that Poland promoted economic reform programs of negotiated restructuring that linked the reorganization of assets with gradual ownership change. Its policies of public administration also gave a variety of government actors the resources and discretion to participate in and monitor these programs.

\section{Blocked restructuring in Czech Manufacturing}

The Czech depoliticization agenda focused on quickly establishing new incentives for private owners and banks to restructure and create new firms. Rapid, mass privatization, coupled with strengthening of the executive and weakening of sub-national government, would not only limit the blocking power of firm stakeholders but also create new equity owners to discipline management and invest. Once recapitalized in 1991, the main banks could use their new creditor rights and the strict bankruptcy law to cut off problem debtors and lead restructuring. Any conflicts among firms and banks over the reorganization of assets would be resolved through contracts, buyouts, and closures, relieving the government of any active role in the economy.

The case of the Czech machine tool sector is an apt example of why the depoliticization agenda actually undermined the stable reorganization manufacturing assets. In general, scholars have viewed a country's machine tool sector, and more broadly its machinery and equipment branch, as an important gauge of industrial restructuring and exports because of its position in the manufacturing value chain. (Herrigel 1996, Cohen and Zysman 1987, Amsden et al. 1994) It also has been viewed as a major source of SME creation and flexible specialization worldwide since the mid-1970s. (Piore and Sabel 1984, Acs and Audretsch 1990, Carlsson 1989) The 
Czech machine tool firms themselves formed the backbone of Czech industry since the early 1900s and were recognized as leading players in the international machine tool market for most of the post WWII period. (McDermott 2002) Moreover, after 1989 the Czech machine tool firms embraced privatization and made conscious attempts to reproduce their old network ties.

By 1991 Czech machine tool firms had already began breaking themselves up into 40 firms, with the six largest organizing plants as semi-autonomous profit centers. This process of coordinated decentralization came out of the sector's inherited polycentric network structure. Figure 2 shows the structure and key actors within the machine tool network as it formed under the umbrella of the communist branch planning association in the 1980s. For instance, member firms had retained considerable decision-making powers and independent financial accounts, but none was a dominant customer or supplier to the others. This structure of several, horizontally associated firms with deep overlapping professional ties is often viewed as facilitating flexibility, coordination, and sharing new knowledge and resources. (Larson 1992, Kogut 2000, Rowley et al. 2000) The firms built on this network form in two ways.

First, the firms and many plants entered the first wave of privatization mainly via vouchers. Second, they sought to balance individual autonomy with group cohesion by grafting indirect equity and financial alliances onto their past social ties. They converted the directorate of their former VHJ into the headquarters of new machine tool association, SST, in which each firm was an owner. As can be seen in Figure 3, SST used its historical ties to create overlapping equity holdings with FINOP and CSOB, the Czech leaders of international trade finance, and their new private bank, Banka Bohemia, in key investment funds and foreign trade companies. SST and the new equity links would provide members with strategic sectoral information and a common coordinating structure in areas where individually they were weak, such as in foreign trade, shared trademarks, critical inputs, vocational training, and development loans. 
By 1995, however, the machine-tool network had fragmented and most firms bordered on insolvency. The attempt by SST members to reinforce their past social relationships with equity ties and contracts and also replace past public external partners with new private financial ones did little to promote cooperation and restructuring.

First, the uncertainties of new production experiments created restructuring conflicts between interdependent firms. Given the lack of knowledgeable suppliers and the high costs of total in-house production, SST firms turned to one another for the development or sub-contracting of certain components and the cost sharing of exporting and importing (especially for CNC electronics). Since the strategies of new product development entailed significant risks and often conflicted with one another, no firm could give the contractual guarantees to the others to forego their own plans and invest in those of the solicitor. For instance, even when the solicitor demonstrated that the trial runs were for a credible international client, the small production volumes and poorly defined future revenue streams undermined the credibility of the project. In turn, the potential SST suppliers refused to alter their own component production for the benefit of the solicitor. ${ }^{6}$

Second, the supporting equity alliances failed to provide needed financing to overcome the hold-up problems among members. Even with the government's partial recapitalization and debtrelief for the banks, CSOB, like the other "big five" Czech banks, still had weak capital bases and tight financial links with industrial and trade firms. But the big Czech banks found it too risky to lead bankruptcies or finance restructuring via the available governance mechanisms of contracts, liquidations, and ownership (debt-equity swaps). (Hoshi et al., 1998) In turn, the big banks refused to provide credit lines directly to firms or via new banks like Banka Bohemia, and SST firms languished. Indeed, in 1994, regulators closed four of the five largest de novo banks, including Banka Bohemia. 
As most collaboration collapsed, ZPS, the largest and most successful SST member, launched a plan in mid 1995 to acquire other SST firms instead of trying to use them as subcontractors. But given ZPS's large debts and obstinacy of the main Czech banks, ZPS used a group of its own small allied investment funds and new banks to channel financing from the their depositors, notably the partially privatized Czech Insurance Company. ZPS and its allies attempted to use these funds to manipulate the share prices of SST firms and gain strategic control of them. This scheme came crashing down in late 1996 when two of ZPS's allied banks went insolvent and regulators seized Czech Insurance.

By tying network reorganization to institution building, an embedded politics approach can make sense of the failure of past social relations and new equity ties to mediate the disputes among SST firms and constrain the domination strategy of ZPS. First, the depoliticization agenda radically altered the network authority structure that underpinned the inherited social capital between firms. As depicted in Figure 2, a key reason for the development of polycentric network during communism was that relevant central bank branches and regional/district administrative party councils had provided many firms of the old VHJ network with political and material resources for bargaining power vis-à-vis other machine tool firms and the central state ministries. Bent on centralizing power during transformation, the Czech government literally and figuratively eliminated the traditional external partners for the firms, removing the power structure that supported the past informal decision-making rules and norms of reciprocity.

Second, to sustain its insularity, the Czech government impeded the development of new institutions for restructuring. Once mass privatization was implemented and bank were partially recapitalized, private contracts and a bankruptcy regime emphasizing liquidation would induce restructuring. Any alternative policies, such as leasing firms, selling assets with typical conditions of restructuring, or promoting workouts as part of bankruptcy, would have linked 
ownership change and restructuring and required government oversight. Moreover, to do so would have demanded empowering different public actors, be they ministries or sub-national governments, with the necessary discretion and resources to share some of the risks and create rules for the relevant parties to negotiate over time the restructuring of both operations and financing. Czech transformation policy, however, strongly curtailed any such delegation of power and public-private deliberations.

As such, Czech firms and their new private external partners - the main banks and investment funds - were left with no mechanisms to help them extend time horizons, share risk, and monitor one another. Liquidation of industrial firms threatened to destroy the future client base of the Czech banks, and using a contract to forge a mutually binding workout agreement was insufficient to protect their investments and build confidence in one another.

\section{Enabling Restructuring and Institutional Experiments in Poland}

As Czech restructuring slumped, Polish industrial output and firm creation accelerated, even in the machinery and equipment branch. ${ }^{7}$ Though not always intentionally, the Polish approaches to privatization, bank reform, policy-making power contrasted sharply with those of the Czechs. These differences are summarized in Table 4. Firm privatization and bank reform policies largely focused on combining restructuring and ownership change. The government effectively delegated to stakeholders limited property rights that also forced them to negotiate with one another over the reorganization and control of assets. At the same time, different central agencies and sub-national governments had the power and incentives to initiate, co-finance, and monitor these activities, often in collaboration with one another. In turn, the Polish transformation approach helped firm and bank actors reorganize their economic linkages, while public actors experimented with their new institutional roles.

Stakeholder Privatization 
The 1990 law on Privatization of State Enterprises reinforced the veto powers of worker councils and effectively blocked rapid, mass privatization. But this law also opened two routes of ownership change that delegated partial use and cash-flow rights to stakeholders of mostly medium-sized firms and plants and gave them incentives to negotiate with one another and restructure assets. By the end of 1996, these routes accounted for more than $68 \%$ and $52 \%$ of non-agricultural and manufacturing firms, respectively, subject to ownership change. Both routes also accounted for more employment than any other route, except for firms commercialized but still with full state ownership. (Jarosz 1999, Nuti 1999, Blaszczyk and Woodward 1999)

The so-called, "liquidation" route, based mainly on Article 19 from 1981, sent firms through a specialized bankruptcy procedure that focused on debt relief and maintaining employment. Over half of assets in completed projects were restructured, kept as going concerns, and sold or leased to a combination of managers, workers, and outsiders. The socalled, "direct privatization" route came through Article 37 of the 1990 Law and was the largest and fastest. This law allowed employee council to legally dissolve its state firm and then have the assets be sold for cash or in-kind contributions or be leased to a new company, usually comprised of insiders. By the end of 1996, 98\% of projects for the 1247 firms in direct privatization were completed, far surpassing the completion rates of all other privatization methods. They accounted for almost $30 \%$ of all non-bank privatization revenues. ${ }^{8}$ Just over half of the employment in these firms was in manufacturing. Over two-thirds of direct privatization projects were from lease options. Lease contracts were 5-10 years and aimed specifically to result in gradual management-employee buyouts (MEBOs) through the lease payments. The new company had to have at least $50 \%$ of employees of the original firm and make an initial down payment of $20 \%$ of book value. Research tracking firms in direct privatization has shown 
that their financial, productivity, and output indicators are better than national and sectoral averages, and by 1998 only 23 MEBO firms had defaulted on their lease payments. ${ }^{9}$

Articles 19 and 37, particularly MEBOs, tied asset restructuring directly to the gradual reordering of property rights. This was possible for three reasons. First, Articles 19 and 37 effectively forced multi-party negotiations, be they for creating a MEBO, keeping a firm as a going concern, or limiting political hold-ups during project selection. Such negotiations between potential owners and stakeholders (e.g., work groups, linked plants and firms) not only helped limit asset theft by any individual group but also forced the different claimants to begin to take into account one another's interests, vital for the development of product and process improvements that reach across firms. Second, both routes relieved financial pressure on the firms, in turn providing breathing for firms to experiment with different restructuring strategies. For instance, lease contracts for MEBOs used below market interest rates and offered the option of deferring initial payments of up to two years. Although MEBO firms had limited access to new capital investment loans, the financial relief typically allowed them to restructure via incremental organizational, process, and product innovations.

Third, rather than cutting itself off from society and monopolizing power, the central government gained a well-placed agent to mediate between different claimants to assets by delegating project approval and monitoring authority to the 49 voivodships (regional administrations). In becoming the legal "founders" of most firms, the voivodships could initiate or block a liquidation petition, evaluated direct privatization projects before they were passed to the central Ministry of Ownership Transformation (MOT) for final approval, and negotiated with MEOB candidates about certain terms of repayment. As they had relatively simple criteria and could maintain much of regional employment, the two privatization routes were politically advantageous for the voivodships. But excesses were monitored not only by the MOT and the 
17 regional fiscal audit offices of the Ministry of Interior but also by the relevant gmina (municipality) officials, which were freely elected, had significant resources, and could monitor regional policies in the voivod council. As we will now see in the next two sections, the political and functional interdependencies increasingly connected the reorganization of economic networks with the creation of regional institutional capabilities.

\section{Polish Workouts of Banks and Large Firms}

The few studies on Polish manufacturing networks show that renewal of initially acrimonious inter-firm relations emerged in part from sub-national governments supporting collective problem-solving and resource flows from large firms to their SME suppliers. (Dornisch 1997, Yolum 2001, Despiney-Zachowska 2001) The latter, however, was hampered by delays in large firm privatization and formal bankruptcy procedures. The Polish government began in 1990-91 to experiment with different methods of intervention into large firms. The most successful cases were the now well-known turnarounds of the Szczecin and Gdynia shipyards, which had been under severe financial distress. (Johnson 1995, Keat 2002) The government's development bank initiated programs that restructured shipyards' debts to its over 1500 creditors (banks and suppliers) and provided trade insurance to the shipyard' main customers. In return, shipyard management, worker's councils, and key suppliers had to initiate a thorough restructuring of operations and the value chain. Progress was evaluated through regular joint meetings among representatives of government, the main banks, and the groups just mentioned. The eventual privatization of both shipyards resulted in an ownership being divided among management, workers, the central government, relevant local governments, the largest suppliers, and the public.

When the growing stock of bad loans to firms threatened financial stability in 1992, the government viewed case-by-case approaches and court proceedings as too slow. The Czech 
response was a one-time partial bank recapitalization, after which the incentives from rapid privatization, new creditor rights, and the bankruptcy as liquidation law would propel the main banks to lead firm restructuring. The Polish government rejected this approach, arguing that it would not change bank-firm relations or government oversight capabilities and would destroy value in the meantime. Rather, the shipyard cases became the basis of a broader government led workout regime that purposefully tied simultaneous bank and firm restructuring with gradual redefinition of property rights. Whereas the Czech approach, which led to failure and another bailout, would cost taxpayers over 25\% of GDP by the end of the 1990s, the Polish approach would cost only 7\% of GDP. (Tang et al. 2000)

In 1993, the Finance Ministry launched the Enterprise and Bank Restructuring Program (EBRP) ${ }^{10}$ The government offered seven of the nine main commercial banks (which held about $60 \%$ of outstanding enterprise debt) a one-time recapitalization sufficient to deal with classified debts that originated prior to 1992. In return, the banks had to establish workout departments and had to reach a debt resolution agreement with their main debtors by March 1994, to be fully implemented by March 1996. Such an agreement allowed for 5 paths, including demonstration of full debt servicing (about $40 \%$ of the 787 total firms), bankruptcy, liquidation, debt sale, and a new regime called "bank conciliation". This last route became the most popular method of dealing with problem firms ( $23 \%$ of firms and $50 \%$ of debt) and was widely judged by outsiders as a successful, efficient policy that significantly improved the performance and governance of banks and firms. (Gray and Holle 1998 and Montes-Negret and Papi 1996)

Since EBRP, and conciliation in particular, demanded regular government evaluation of decentralized actions taken by banks and firms, the governance principles again were delegation of restructuring authority to stakeholders, multi-party risk sharing, and government monitoring via iterative deliberations among the parties to assets. First, the Deputy Finance Minister 
purposefully used regular deliberations to enhance monitoring and learning. After receiving the restructuring authority and the basic criteria of EBRP, the lead managers of the workout departments of the seven banks met together every month for over a year with relevant representatives of the Finance Ministry, the Privatization Ministry, the Central Bank's supervisory division, and the state auditor. In these meetings, the banks had to reveal how they were and were not making progress in the restructuring of their own balance sheets and the firms. The collective, iterative evaluation process created a constant flow of information, which government officials and bank managers used to compare and rate one another's actions over time, detect flaws, limit favoritism, and negotiate updated terms of workouts. At the same time, the deliberations allowed the banks to learn from one another the pitfalls and benefits of different restructuring methods and the government actors to learn how to improve their own auditing and monitoring techniques.

Second, a similar negotiation process with creditors, firms, and regional public officials took place at the regional level. For instance, in his detailed analysis of the turnaround in heavily industrialized region of Lodz, Dornisch $(1997,2000)$ notes that the negotiations between the regional bank, voivodship (as the founder of the firms), the local tax office and firm management led to new channels of information sharing. As the voivodship learned to forge compromises between the bank and firms, the three parties extended workout negotiations to include the gradual reorganization of supply networks. As a result, EBRP framework not only helped large firms and their suppliers redefine the terms of their common production lines, but also led the bank to develop new services. The Lodz bank soon developed successful regional equity and venture capital funds out of its workout department. This bank and others also developed special write-off provisions for SME suppliers of the large firms included in EBRP. 
Taken together, direct privatization and EBRP created concrete frameworks for stakeholders to pursue restructuring experiments while gradually redefining their common claims to assets. To support and effectively monitor such negotiated solutions, the central government could not isolate itself but had to empower public actors at various levels of society. This marks a third fundamental different between the Polish and Czech approaches to transformation: the distribution of public power. Regional and local governments in Poland were facilitating network reorganization not simply as agents of the central state but also as builders of new institutional capacities in their own right.

\section{Institution Building and the Political Matrix of Sub-National Governments}

Both Polish and Czech reformers were highly concerned about continued control by communist apparatchiks of regional and local councils and maintaining a unitary state. But their methods of dealing with them contrasted sharply. ${ }^{11}$ The Czechs eliminated regional councils, allowed municipal and district councils to fragment into numerous small uncoordinated units, and restricted their participation in economic reforms. In contrast, the Poles 49 maintained voivodships, and gminas are considerably fewer and larger than their Czech counterparts, with greater stocks of resources and autonomy over revenues and expenditures. (OECD 2000) For instance, Gorzelak (1998) estimates that gminas provided about $50 \%$ of new public infrastructure in Poland during the 1990s. This resource distribution provided sources of policy initiative as well as the basis for inter-governmental bargaining power and monitoring within the regional political matrix.

On the one hand, a voivodship governor was directly responsible to the central government, had specific mandates in privatization and restructuring, and was charged with ensuring the legality of gmina policies. (Regulska 1997) On the other hand, voivodships could not ignore the gminas. The central government usually consulted with gminas over the 
appointment of a voivod governor. The voivod council, comprised of gmina representatives, reviewed all voivodship policies, although the gminas did not have formal veto powers, other than withholding resources and lobbying the central government. In turn, the Polish government economic reforms not only employed well positioned agents to implement policy but also triggered a variety of public actors to monitor and collaborate with one another in supporting firm restructuring and creation within the well-balanced matrix of political autonomy and interdependence.

To become an effective participant in policies like direct privatization and EBRP, a voivodship typically combined its relative authority and organizational resources with the social, informational, and human resources of the regional bank, firms, consultants, gminas and the audit agency. These initial steps became a resource for gminas and economic actors to expand their portfolios of strategies, collaborators and project screening capabilities. For instance, when EBRP was launched, the regional banks lacked effective monitoring capabilities. In turn, they began to supplement their deficiencies by participating in regular voivod council meetings and accessing the voivod data base. The pilot experience in restructuring firms in EBRP, and in some case becoming co-owners of them, led the Lodz Bank and voivodship to co-manage a closed World Bank investment fund for initially 20 firms. (Dornisch 1999, 2000)

This interaction led to a dramatic rise in local and regional public-private institutions, such as 1500 business support centers and 23 mutual loan guarantee funds, to support large firm restructuring, SME growth, and manufacturing networks. (Woodward 2001, Gorzelak 1998, Yolum 2001) Such institutions grew out of Regional Development Agencies (RDAs). By 1996, Poland had 66 RDAs throughout the country, whereas the Czech Republic had only two. With initial support of the Polish Agency for Regional Development and the Industrial Development Agency (IDA), gminas, voivodship, and firms created RDAs mainly to provide low cost services 
to new and transforming state firms that alone could not access them. As RDAs are typically joint stock companies, the most significant owners are usually voivodships, gminas and the IDA. Firms saw RDAs as critical sources of consulting, training, investment promotion, business incubators, and loan guarantees. (Gorzelak 1998) Indeed, when comparing regions, researchers have found high and strong positive relationships between the density and diversity of publicprivate institutions, on the one hand, and relatively high rates industrial restructuring, participation in direct privatization (especially via MEBOs), SME creation, and the reception of FDI on the other. (Hausner et al. 1995, 1997, 1998; Jarosz 1999)

Although initiatives related to RDAs and firm restructuring were often fraught with delays and failures, the political and resource interdependencies demanded that the relevant regional public and private actors continually renew the process of collective problem solving. (Dornish 1997, 2000) In being forced to jointly administer and evaluate privatization, restructuring and development projects early on, the relevant firm, bank, and government actors began to learn about how to monitor one another and share authority over common assets. This experience in turn helped them define a reasonable set of new common projects and how to assess one another's actions and contributions. Institutional development was not coming from a grand design from above but from stakeholders finding ways to address one another's interests while experimenting with new institutions roles for the demands of asset reorganization.

\section{Concluding Remarks}

This essay has argued that an embedded politics approach may prove more useful than depoliticization and continuity approaches in analyzing restructuring and firm creation, at least in East Central Europe. Similar to recent work by Woodruff (1999), Jacoby (2000), and Johnson (2001), my approach is an attempt to bring issues of political power and democratic governance back into the debates on institutional change and economic reform. The value-added of my 
approach is that it is more explicit about how the distribution of political power can impact both productive outcomes and the open-ended process of constructing new institutions.

Socio-political networks mediate between two simultaneous, interdependent experiments -- micro-level experiments by firms and banks to reorganize common assets and macro-level experiments by policy-makers to build new institutions. The restructuring of networked assets demand institutional workout mechanisms that help the different claimants negotiate over time the redistribution of risk and property rights. Since public actors are both constituents to networks and often key players in such institutions, restructuring in turn depends on the ways that different national and sub-national organs are given the legitimacy and resources to explore their roles as risk-sharers, initiators, and monitors of the negotiations.

At one level, inter-linked firms and banks are attempting to learn how construct new formal and informal methods of mutual monitoring and project selection. This is where asset restructuring is tied to network reorganization. At another level, public actors, be they the central agencies or regional governments, are learning how to provide financial and organizational support to firms and banks while experimenting with different ways to monitor the latter. In turn, the embedded politics approach argues that public actors are most effective in combining learning and monitoring, for themselves and for economic actors, when transformation policies are based on the principles of delegation and deliberation.

This essay has tried to show that Poland created political conditions more conducive for institutional experimentation. Czech impediments to institutional experiments came not only from the government's attempt to rapidly privatize firms and banks but also from its attempt to create and maintain an autonomous, powerful central policy-making apparatus. In contrast, Poland's relative economic success in the 1990s came from economic policies that linked the reorganization of assets with gradual ownership change as well as institutional policies that gave 
a variety of government actors the resources and discretion to participate in restructuring and monitor one another's actions.

In trying to connect the politics of institutional change to economic restructuring, my argument invites two areas of additional scrutiny. First, the essay suggests that the creation of public-private institutions that induce risk sharing and mutual monitoring are vital to economic development. I have emphasized here the role of workout institutions, but institutions such as loan guarantee systems for mortgages and SMEs, lender of last resort, deposit insurance, limited liability, and subsidized working training and $\mathrm{R} \& \mathrm{D}$ are all equally important in advanced industrialized countries. The importance of such institutions is that they help private actors invest in relatively uncertain activities while providing systemic stability. They however open up the risks of moral hazard and adverse selection, because of the inherent socialization of risk. But just as the creation of investor protection institutions demand government oversight and enforcement capabilities, so too do these other institutions demand the creation of government capabilities to initiate and monitor risk sharing programs. The dual challenge for researchers is not only to determine the impacts of such institutions on productive outcomes but also to capture how public actors experiment with these new roles. This experimentation is above all about building up effective monitoring capabilities to learn where government is needed most and how it can ensure efficient use of public funds.

Second, this essay also suggests that organization of political power impacts the governance of institutional experimentation. My discussion of the importance of sub-national administrations was meant simply to illustrate that institutional experimentation requires, at a minimum, the empowerment of a variety of government actors to explore different policy approaches and have the political voice to relay them back to higher-level bodies. There is a significant body of research on advanced industrialized countries (Locke 1995, Herrigel 1996, 
Saxenian 1994, Piore and Sabel 1984), developing countries like Brazil and China (Tendler 1997, Oi 1999), and even in Russia (Petro 2001) that show that sub-national governments play critical roles in facilitating economic development and becoming laboratories for new public policy. At the same time, however, it would be misguided to think that simply decentralization is the answer to development, as it can equally turn into grounds for local strongmen and corruption. Rather, the evidence presented on Poland suggests that effective institutional development comes not only from empowering local public and private stakeholders but also how policies and political institutions are created to enhance mutual monitoring. Indeed, the research on Russia (Woodruff 1999), China (Oi 1999, Oi and Walder 1999), Brazil (Tendler 1997), and Argentina (Jones et al. 2002) has also shown that the differences in the distribution and governance of policy-making power among sub-national governments can account for the ability of countries to initiate and sustain institutional reforms. I have argued that the governance principles of delegation and deliberation may turn the potential for local abuse and self-dealing between public and private actors into benefits for the public welfare. In this view, then the ability of the 1999 reforms in Polish sub-national governments to sustain the gains made in the 1990s would depend on how the reforms supported or undermined these governance principles. But whether you fully agree or not with that argument, though, is perhaps less important than moving research on economic development away from the ideal designs at the commanding heights and toward the way polities govern institutional change at multiple levels of society. 
Table 1: Divergence in SME Growth in Manufacturing Firms with Less than 250 Employees

\begin{tabular}{|l|c|c|}
\hline & $\begin{array}{c}\text { Czech Republic } \\
(1989-1997)\end{array}$ & $\begin{array}{c}\text { Poland } \\
(1989-1997)\end{array}$ \\
\hline $\begin{array}{l}\text { Change in Share of Employment in } \\
\text { Private Sector Firms (\%) }\end{array}$ & $\mathbf{4 6 . 3 \%}$ & $\mathbf{5 4 . 2 \%}$ \\
\hline
\end{tabular}

Sources: Czech Statistical Office (Author's calculations); Polish Foundation for SME Promotion and Development (1999).

Table 2: Divergence in Privatization (1995)

\begin{tabular}{|l|c|c|c|c|}
\hline & $\begin{array}{c}\text { \%o of GDP in } \\
\text { Private Hands }\end{array}$ & $\begin{array}{c}\text { \% of firms in } \\
\text { Private Hands }\end{array}$ & $\begin{array}{c}\text { \% of Industrial } \\
\text { Output in } \\
\text { Private Hands }\end{array}$ & $\begin{array}{c}\text { \% of Bank } \\
\text { Assets w/in State } \\
\text { Banks }\end{array}$ \\
\hline Czech Republic & 70 & 90 & 93 & 19.5 \\
\hline Poland & 60 & 46 & 60 & 71.1 \\
\hline
\end{tabular}

Sources: EBRD (1996), Pohl et al. (1997), World Bank (1996), Tang et al. (2000)

Table 3. Key Economic and Financial Indicators for the Czech Republic and Poland

\begin{tabular}{|c|c|c|c|c|c|c|c|c|}
\hline & \multirow{2}{*}{$\begin{array}{c}\text { Change in } \\
\text { Real } \\
\text { GDP, } \\
\text { 1989-98 }\end{array}$} & \multirow{2}{*}{$\begin{array}{c}\text { Change in } \\
\text { Industrial } \\
\text { Labor } \\
\text { Productivity, } \\
1989-98\end{array}$} & \multicolumn{2}{|c|}{ Budget Deficit/GDP } & \multicolumn{2}{|c|}{ Foreign Debt/GDP } & \multicolumn{2}{|c|}{ Debt Service/Exports } \\
\hline & & & 1992 & 1998 & 1992 & 1998 & 1992 & 1998 \\
\hline $\begin{array}{l}\text { Czech } \\
\text { Republic }\end{array}$ & $-4 \%$ & $+13.6 \%$ & $3.1 \%$ & $1.6 \%$ & $23.0 \%$ & $44.7 \%$ & $12.0 \%$ & $14 \%$ \\
\hline Poland & $+17 \%$ & $+42.2 \%$ & $6.7 \%$ & $2.4 \%$ & $57.7 \%$ & $27.1 \%$ & $16.0 \%$ & $9.0 \%$ \\
\hline
\end{tabular}

Sources: Kawalec (1999), Business Central Europe (Selected years at www. bcemag.com) 
Table 4. Contrasting Approaches to Building Workout Mechanisms in Manufacturing

\begin{tabular}{|c|c|c|}
\hline Policy Issue & Czech Republic & Poland \\
\hline Ownership Change & $\begin{array}{l}\text { Rapid, Mass Privatization via } \\
\text { Vouchers. }\end{array}$ & $\begin{array}{l}\text { Gradual methods linked with } \\
\text { restructuring, mostly via "liquidation" } \\
\text { and "direct" privatization, esp. until } \\
1996 \text {. }\end{array}$ \\
\hline Bank Restructuring & $\begin{array}{l}\text { One-time partial debt write-off \& } \\
\text { recapitalization. }\end{array}$ & $\begin{array}{l}\text { Enterprise Bank Restructuring } \\
\text { Program (EBRP), 1993-96, links bank } \\
\text { and large firm restructuring. }\end{array}$ \\
\hline \multirow[t]{2}{*}{ Firm Restructuring } & \multirow{2}{*}{$\begin{array}{l}\text { - Contracts and strict bankruptcy } \\
\text { law focused on liquidation } \\
\text { - Failed attempt to net-out inter- } \\
\text { firm debt. }\end{array}$} & Large Firms - EBRP. \\
\hline & & $\begin{array}{l}\text { Medium \& Small Firms-- } \\
\text { "liquidation" and "direct" methods of } \\
\text { privatiz'n (e.g., leasing). }\end{array}$ \\
\hline $\begin{array}{l}\text { Organization of } \\
\text { Policymaking } \\
\text { - National Level }\end{array}$ & $\begin{array}{l}\text { Strong, autonomous change team in } \\
\text { Mins. of Finance \& Priv'n focus of } \\
\text { rapid implementation of vouchers, } \\
\text { bank recapitalization, and new } \\
\text { laws. }\end{array}$ & $\begin{array}{l}\text { Mins. of Finance \& Priv'n build } \\
\text { capabilities to initiate and monitor } \\
\text { EBRP \& gradualist methods of priv'n; } \\
\text { Build strong regulations for capital } \\
\text { market; Give roles to sub-nat'l gov'ts. }\end{array}$ \\
\hline $\begin{array}{l}\text { - Sub-national } \\
\text { Levels }\end{array}$ & $\begin{array}{l}\text { - Regional councils eliminated; } \\
\text { - Districts and Municipalities } \\
\text { fragmented and weak. }\end{array}$ & $\begin{array}{l}\text { - Voivodships (regional gov'ts) } \\
\text { empowered to screen and monitor } \\
\text { priv'ns, assist in EBRP, build RDAs; } \\
\text { - Gminas (municipalities) work with } \\
\text { Voivodships on restructuring, RDAs } \\
\text { and bond market. }\end{array}$ \\
\hline
\end{tabular}


William Davidson Institute Working Paper 590

FIGURE 1. Industrial Production in the Czech Republic and Poland

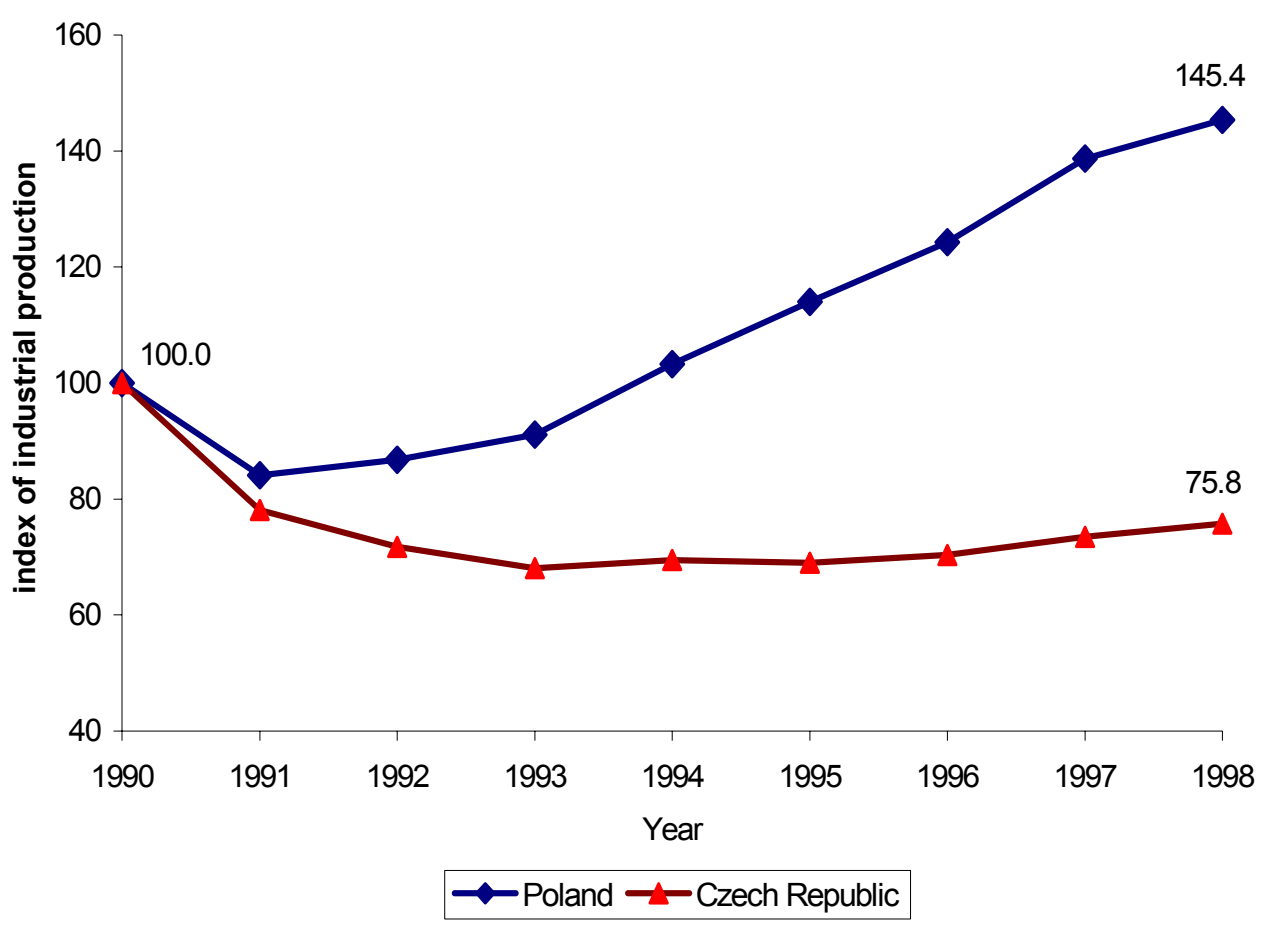

Source : OECD (1999) in Spicer et al. (2000) 


\section{Figure 2: Polycentric Network (e.g., TST VH)}

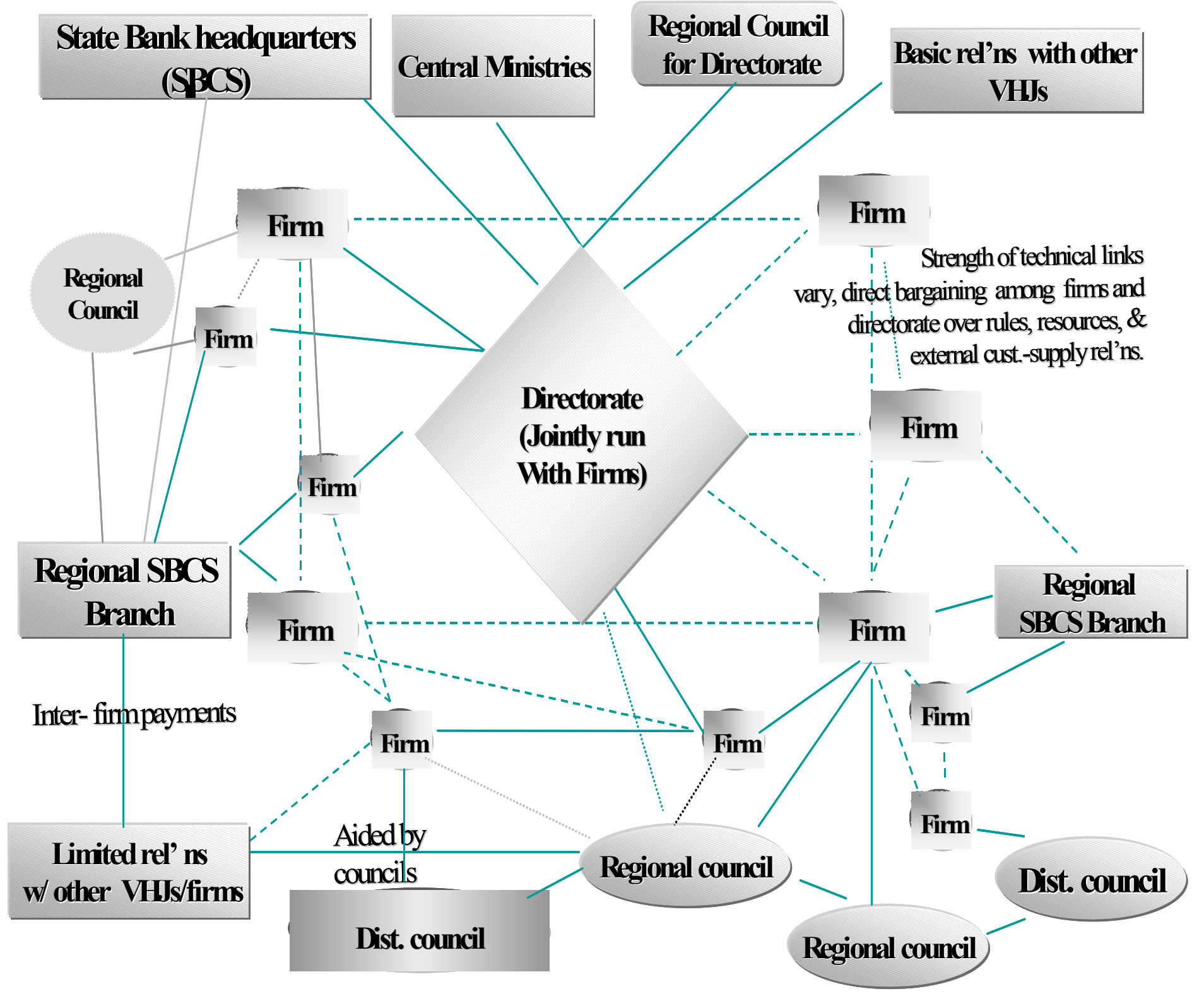




\section{FIGURE 3: Network Ties in the Czech Machine Tool Industry}

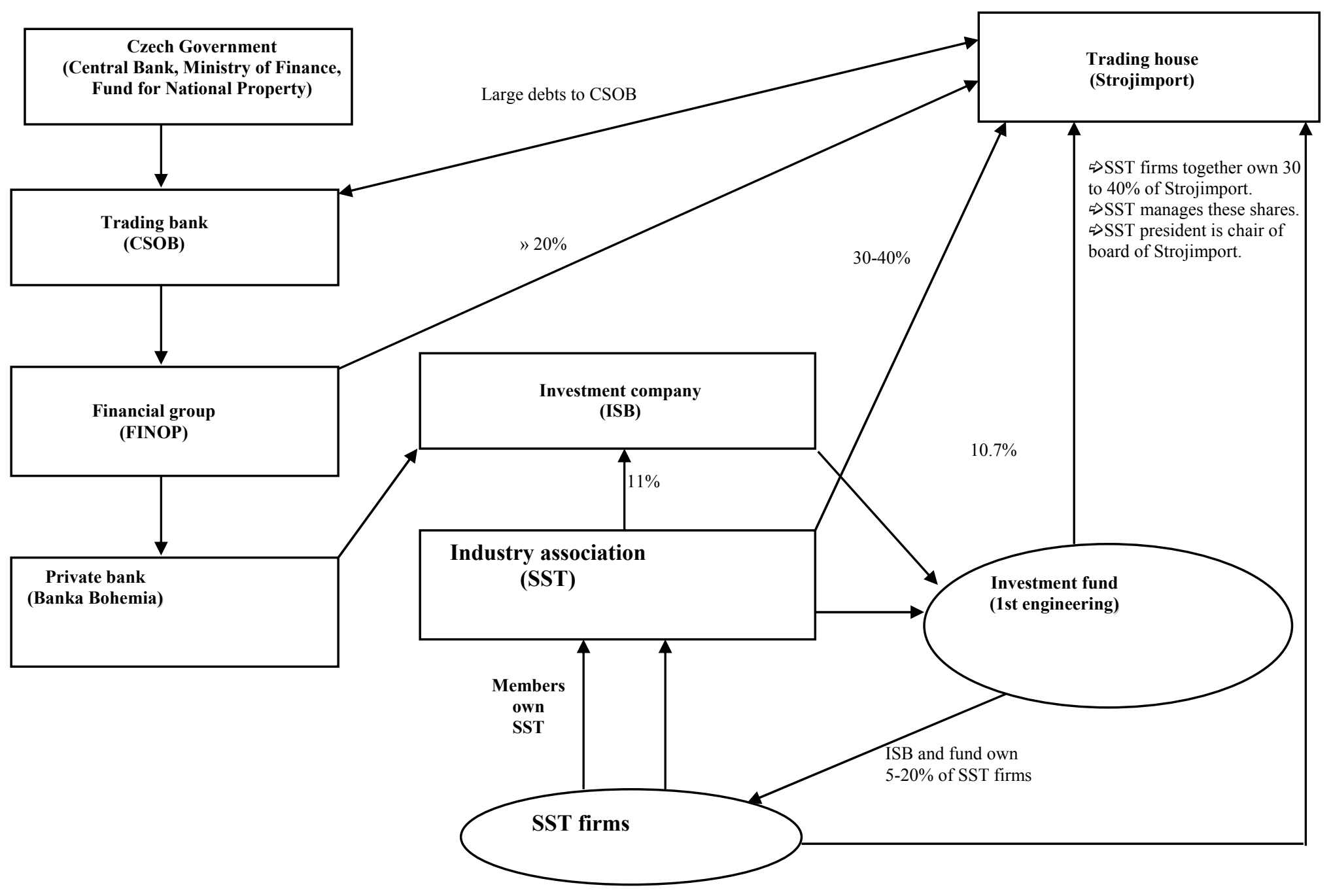




\section{References}

Acs, Z. and D. Audretsch, 1990, Innovation and small firms. Cambridge: MIT Press.

Amsden, Alice H., Jacek Kochanowicz, and Lance Taylor, 1994, The Market Meets its Match:

Restructuring the Economies of Eastern Europe. Cambridge: Harvard University Press.

Baldersheim, H., M. Illner, A. Offerdal, L. Rose, and P. Swianiewicz, eds., 1996, Local Democracy And The Processes Of Transformation In East-Central Europe. Colorado: Westview Press.

Blaszczyk, B. And R. Woodward, eds., 1999, Privatization and Company Restructuring in Poland, Case Reports No. 18, Center for Social and Economic Research, Poland.

Boycko, M., Shleifer, A., \& Vishny, R. 1995. Privatizing Russia. Cambridge, MA: MIT Press.

Bratkowski, A., Grosfeld, I., and Rostowski, J., 1999, "Investment and Finance in De Novo Private Firms: Empirical Results from the Czech Republic, Hungary, and Poland," Working Paper No. 236, The William Davidson Institute, The University of Michigan Business School.

Camdessus, M. 1994. "Supporting Transition in Central and Eastern Europe: An Assessment and Lessons from the IMF's Five Years' Experience," Second Annual Francisco Fernández Ordóñez Address, Madrid, Spain, December 21.

Carlsson, B., 1989, "Small-Scale Industry at a Crossroads: U.S. Machine Tools in a Global Perspective," Small Busienss Economics, 1(4): 245-261.

Cohen, Joshua and Charles Sabel, 1997, "Directly-Deliberative Polyarchy," European Law Journal, 3(4), pp. 313-340.

Coffee, J. 1999, "Privatization and Corporate Governance: The Lessons from Securitites Market Failure," Working Paper No. 158, The Center for Law and Economic Studies, Columbia Law School.

Cui, Z., 1995, "The Dilemmas of the Soft Budget Constraint: Three Institutions that Challenge the 'Invisible Hand' Paradigm," PhD. Dissertation, Department of Political Science, University of Chicago.

Dabrowski, Janusz M., Michal Federowicz, and Anthony Levitas, 1991, "Polish State Enterprises and the Properties of Performance: Stabilization, Marketization, Privatization," Politics and Society, 19(4): 430-437.

Despiney-Zachowska, Barbara, 2001, "Neo-Marshallian Districts - A Possible Interpretation of Polish Regional Development?” ROSES, Université Paris 1, mimeo. 
Dornisch, David, 1997, “An Ecology Of Projects: Economic Restructuring And Network Recombination In Post-Socialist Poland,” Ph.D. Dissertation, Department of Sociology, Cornell University.

, 1999, "Project Networks vs. Networks Of Cooperation: Regional Restructuring And Governance In Post-Socialist Poland,” BISS Public, 27: 73-103.

, 2000, "The Social Embeddedness of Polish regional Development: Representative Institutions, Path Dependencies, and Network Formation," mimeo.

Frydman, Roman and Andrzej Rapaczynski, 1994, Privatization in Eastern Europe: Is the State Withering Away? London: Central Europe University Press.

Granovetter, M. 1985, "Economic Action And Social Structure: The Problem Of Embeddedness," American Journal of Sociology, 91: 481-510.

Gray, C and A. Holle, 1998, "Poland's Bank-led Conciliation Process," in Balcerowicz, Gray and Hoshi, eds., Enterprise Exit Processes in Transition Economies. Budapest: CEU Press.

Grindle, Merilee. 1991. "The New Political Economy: Positive Economics and Negative Politics." In Politics and Policy Making in Developing Countries: Perspectives on the New Political Economy, edited by Gerald M. Meier. San Francisco: ICS Press.

Haggard, S. and R. Kaufman, 1992, "The State in the Initiation and Consolidation of MarketOriented Reforms," in D. Rueschemeyer and L. Putterman, eds., State and Market in Development: Synergy or Rivalry? Boulder: Lynne Reiner.

Press.

, 1995, The Political Economy of Democratic Transitions. Princeton: Princeton University

Halkier, Henrik, Mike Danson, and Charlotte Damborg. 1998. Regional Development Agencies in Europe. Philadelphia: Jessica Kingsley Publishers.

Hayri, A., \& McDermott, G. A. 1998. The network properties of corporate governance and industrial restructuring: A post-socialist lesson. Industrial and Corporate Change, 1: 153-193.

Hausner, J., Kudlacz, T., and Szlachta, J., 1995, Regional and Local Factors in the Restructuring of Poland's Economy. Krakow: Krakow Academy of Economics.

, 1997, "Restructuring in South-Eastern Poland," in G. Grabher, \& D. Stark (Eds.), Restructuring networks in postsocialism: Legacies, linkages, and localities. Oxford: Oxford University Press.

, 1998, "Regional Differentiation of Factors Conditioning the Growth of Innovativeness in Poland's Economy," in R. Domański, ed. Emerging Spatial and Regional Structures of an Economy in Transition. Warszawa: Wydawnictwo Naukowe PWN. 
Herrigel, G. 1996. Reconceptualizing the sources of German industrial power. New York: Cambridge University Press.

Hoshi, I, J. Mladek, and A. Sinclair, 1998, "Bankruptcy and Owner-Led Liquidation in the Czech Republic," in Balcerowicz, Gray, and Hoshi, eds., Enterprise Exit Processes in Transition Economies. Budapest: CEU Press.

Jacoby, W., 2000, Imitation And Politics: Redesigning Germany. Ithaca: Cornell University Press.

Jarosz, M., ed., 1996, Polish Employee-Owned Companies in 1995. Warsaw: Institute of Political Studies, Polish Academy of Sciences.

, 1999, Direct Privatization: Investors, Managers, and Employees. Warsaw: Institute of Political Studies, Polish Academy of Sciences.

Johnson, J, 2001, "Path Contingency in Postcommunist Transformations," Journal of Comparative Politics, 33(3): 253-74.

Johnson, S. and G. Loveman, 1995, Starting Over In Eastern Europe : Entrepreneurship And Economic Renewal. Boston: Harvard Business School Press.

Johnson, S., J. McMillan, and C. Woodruff, 2000, "Entrepreneurs and the Ordering of Institutional Reform," Economics of Transition, 8(1): 1-36.

Johnson, S. and Shleifer, A., 1999, "Coase vs. The Coasians: The Regulation and Development of Securities Markets in Poland and the Czech Republic," Working Paper, Social Science Research Network.

Jones, Mark, Sebastian Saiegh, Pablo Spiller, and Mariano Tommasi, 2002, “Amateur Legislators-Professional Politicians: The Consequences of Party-Centered Electoral Rules in a Federal System” American Journal of Political Science, 46(3): 656-669.

Keat, Preston, 2002, "Playing Favorites: Government Aid and Industrial Restructuring in PostSocialist Poland" Doctoral Dissertation, Department of Political Science, University of California, Los Angeles.

Kogut, B., 2000, “The Network as Knowledge: Generative Rules and the Emergence of Structure," Strategic Management Journal, 21: 405-425.

Kornai, J., 1990, The Road to Economic Freedom. New York: Norton.

Kozarzewski, P. and R. Woodward, 2000, "Firms Privatized by Employee Buyouts in Poland: Enterprise Performance and the Evolution of Ownership Structure," unpublished manuscript from the CASE Foundation, Warsaw, Project, "Secondary Privatization: The Evolution of Ownership Structure of Privatized Companies," funded by the European Union's Phare ACE Program 1997, project P97-8201 R. 
Larson, A., 1992, "Network Dyads in Entrepreneurial Settings: A Study of the Governance of Exchange Relationships," Administrative Science Quarterly, 37: 76-104.

Levitas, A. 1994. Rethinking reform: Lessons from Polish privatization. In V. Milor (Ed.), Changing political economies: Privatization in post-communist and reforming communist states: p 99-114. London: Lynne Rienner.

, 1999, The Political Economy of Fiscal Decentralization and Local Government Finance Reform in Poland 1989-99, Research Triangle Institute, unpublished manuscript.

Lieberman, I. 1997. Mass privatization in comparative perspective. In I. Lieberman, S. Nestor, \& R. Desai (Eds.), Between State And Market: Mass Privatization In Transition Economies: p 118. Washington, DC: World Bank.

Locke, R., 1995, Remaking The Italian Economy: Local Politics And Industrial Change In Contemporary Italy. Ithaca, NY: Cornell University Press.

McDermott, G. 1997. Renegotiating the ties that bind: The limits of privatization in the Czech Republic. In G. Grabher, \& D. Stark (Eds.), Restructuring networks in postsocialism: Legacies, linkages, and localities. Oxford: Oxford University Press.

McDermott, G., 2002, Embedded Politics: Industrial Networks and Institutional Change in Post Communism. Ann Arbor: University of Michigan Press. (Forthcoming).

McDermott, G. and M. Mejstrik, 1992, "The Role of Small Firms in the Industrial Development and Transformation of Czechoslovakia," Small Business Economics, 4(3) pp. 179-200.

Montes-Negret, F. And Papi, L., 1996, "The Polish Experience in Bank and Enterprise Restructuring," Financial Sector Development Department, World Bank, unpublished manuscript.

Moon, C. and R. Prasad, 1994, "Beyond the Development State: Networks, Politics, and Institutions,"_Governance: An International Journal of Policy and Administration, 7(4): 360-386.

Moss, D. A., 1996, Socializing Security: Progressive-Era Economists and the Origins of American Social Policy. Cambridge: Harvard University Press.

Murrell, P., 1993, “What is Shock Therapy? What did it do in Poland and Russia?” Post-Soviet Affairs, 9(2), pp. 111-140.

Nellis, J. 1999. "Time to rethink privatization in transition economies?" Finance and Development, June: 16-19.

Nuti, D.M., 1999, "Employee Ownership in Polish Privatizations," in Hare, Batt, and Estrin, eds., Reconstituting the Market: The Political Economy of Microeconomic Transformation. Amsterdam: Harwood Academic Publishers. 
OECD, 1996, Transition at the Local Level: The Czech Republic, Hungary, Poland, and the Slovak Republic. Paris: Organization for Economic Cooperation and Development.

OECD. 1999. Main economic indicators. CD-ROM, Paris: Organization for Economic Cooperation and Development.

OECD, 2001, "Fiscal Design Across Levels of Government: Year 2000 Surveys," Directorate for Financial, Fiscal and Enterprise Affairs Fiscal Affairs, May 15.

Oi, Jean, 1999, Rural China Takes Off: Institutional Foundations of Economic Reform. Berkeley: University of California Press.

Oi, Jean and Andrew Walder, 1999, Property Rights and Economic Reform in China. Stanford: Stanford University Press.

Petro, Nicolai N., 2001, "Creating Social Capital in Russia: The Novgorod Model," World Development, 29(2): 229-244.

Piore, M., \& Sabel, C. 1984. The Second Industrial Divide. New York: Basic Books.

Pohl, G., R. Anderson, S. Claessens, and S. Djankov, 1997, "Privatization and Restructuring in Central and Eastern Europe: Evidence and Policy Options," World Bank Technical Paper No. 368, The World Bank, Washington D.C.

Polish Foundation for Small and Medium Enterprise Promotion and Development, 1999, Report on the Condition of the Small and Medium-Size Enterprise Sector in Poland for the Years 19971998. Warsaw: PAB-Font.

Powell, W. 1990. Neither market nor hierarchy: Network forms of organization. In L. L. Cummings \& B. M. Staw (Eds.), Research in organizational behavior, vol. : :295-336. Greenwich, CT: JAT Press.

Prokop, Jane, 1995, "Industrial Conglomerates, Risk Spreading, and the Transition in Russia," Communist Economies \& Economic Transformation, 7(1), pp. 35-50.

, 1996, Marketization in Russia's Regions, 1990-1994, Doctoral Dissertation, Department of Government, Harvard University.

Przeworski, A. 1991. Democracy and the Market. New York: Cambridge University Press.

Putnam, Robert, R. Leonardi, and R. Nanetti, 1993, Making Democracy Work: Civic Traditions in Modern Italy. Princeton: Princeton University Press.

Ragin, C. 1987. The comparative method: Moving beyond qualitative and quantitative strategies. Berkeley: University of California Press. 
Rowley, T., D. Behrens, and D. Krackhardt, 2000, "Redundant Governance Structures: An Analysis of Structural and Relational Embeddedness in the Steel and Semiconductor Industries," Strategic Management Journal, 21: 369-386.

Sabel, C., 1994, "Learning by Monitoring: The Institutions of Economic Development," in N. Smesler and R. Swedberg, eds., The Handbook of Economic Sociology. Princeton: Princeton University Press.

Sachs, J., 1990, "Eastern Europe's Economies," Economist, January 13. , 1993. Poland's Jump To The Market Economy. Cambridge, MA: MIT Press.

Saxenian, A. 1994. Regional Advantage: Culture and Competition inSilicon Valley And Route 128. Cambridge, MA: Harvard University Press.

Seleny, A., 1993, The Long Transformation: Hungarian Socialism, 1949-1989. PhD. Dissertation, Department of Political Science, MIT.

Shleifer, A., \& Vishny, R. 1994. Privatization in Russia: First steps. In O. Blanchard, K. Froot, \& J. Sachs (Eds.), The transition in Eastern Europe: Restructuring, 2: 137-164. Chicago: University of Chicago Press.

Spicer, A., G. McDermott, and B. Kogut, 2000, "Entrepreneurship and Privatization in Central Europe: The Tenuous Balance Between Destruction and Creation, " Academy of Management Review, Vol. 25, No. 3, pp. 630-649.

Stark, D., 1986, "Rethinking Internal Labor Markets: New Insights form a Comparative Perspective," Amercian Sociolgical Review, 51: 492-504. , 1989, "Coexisting Organizational Formsin Hungary’s Emerging Mixed Economy," in Nee and Stark (eds.), Remaking the Economic Institutions of Socialism. Stanford: Stanford University Press.

, 1996, "Recombinant Property in East European Capitalism," American Journal of Sociology, 101:993-1027.

Stark, D. and L. Bruszt, 1998, Post-Socialist Pathways: Transforming Politics and Property in Eastern Europe. New York: Cambridge University Press.

Szelenyi, I., 1988, Socialist Entrepreneurs. Cambridge: Polity Press.

Tang, H., E. Zoli, and I. Klytchnikova, 2000, "Banking Crises in Transition Economies: Fixed Costs and Related Issues," Policy Research Working Paper 2484, World Bank.

Tendler, Judith. 1997. Good Government in the Tropics. Baltimore: Johns Hopkins University Press 
Walder, A. 1994. Corporate organization and local government property rights in China. In V. Milor (Ed.), Changing political economies: Privatization in post-communist and reforming communist states: London: Lynne Rienner.

Woodruff, D., 1999, Money Unmade: Barter and The Fate Of Russian Capitalism. Ithaca: Cornell University Press.

Woodward, Richard, 2001, "SME Support in Post-Communist Countries: Moving from Individual to Cooperative Approaches (Reflections on the Polish Case)," MOCT-MOST, 11: 275 294.

World Bank Development Report 1996, From Plan to Market. New York: Oxford University Press.

World Bank. 1999. Czech Republic: Capital market review. Washington, DC: World Bank.

Yolum, Denis, 2001, "Patterns of Industrial Upgrading in the Clothing Industry in Poland and Romania," Centre for the Study of Economic and Social Change in Europe, University College London, Working Paper No. 19. 
William Davidson Institute Working Paper 590

\section{Endnotes}

${ }^{1}$ Although Czechoslovakia (CSFR) split in January 1993, I focus on the Czech Republic. There was strong continuity in policy for the Czech lands before and after the split, as the main economic policy makers for the CSFR and the Czech Republic remained largely the same. All firms analysed below were always part $\mathrm{f}$ the Czech lands as well. The network, firm and institutional data for the Czech Republic come from mainly my field work between 1993 to 1996, during which time I conducted over 130 interviews with relevant ministerial, bank, and firm actors and collected primary and secondary firm, bank, and sectoral level data. (See McDermott, 2002) The Polish data come mainly from secondary sources cited below as well as interviews with relevant firm, bank, and government officials in February 2002.

2 See McDermott (2002) for a discussion of depoliticiation views as they appear in economics, rational choice, and developmental statism. My critique draws on observations by Mood and Prasad (1994), Grindle (1991), and Murrell (1993). For examples see Shleifer and Vishny (1994), Sachs (1990), and Haggard and Kaufman $(1992,1995)$.

${ }^{3}$ Actually, Johnson and Loveman build on the seminal argument of Janos Kornai (1990). Kornai argued that growth would come from the liberalized second economy. In the meantime, the state would have to reassert governance control over managers in the state sector. But Kornai appears to also draw a sharp line between the new private sector (or new firms) and the existing state sector.

${ }^{4}$ The structural sociological veiws can be found in Putnam et al. (1993) and Chavance and Magnin (1997). Leading reviews on networks include Granovetter (1985), Powell (1990), Rowley et al. (2000), Kogut (2000), Larson (1992). Apllications of this work on East European firm restructuring and creation include Spenner et al. (1998) and Sedatis (1997).

${ }^{5}$ For work on the former USSR, Poland, GDR, and Hungary, see, for instance, Prokop (1996), Woodruff (1999), Dornisch (1997, 1999), Jacoby (2000), Seleny (1993), Szelenyi (1988), Dambrowski et al. (1991) and Levitas (1994). Even in Stark and Bruszt (1998), there are strong suggestions of the interconnection between local political actors and managers (see, for instance, Ch. 4). This approach draws on work on advanced industrial districts, such as Locke (1995), Piore and Sabel (1984) and Herrigel (1996).

${ }^{6}$ Similar fates met efforts to clarfiy firm specializations, collaborate in exports and imports, and use the vocational training system. An added fear was that firms were beginning to encroach on one another's traditional prodcut lines. See McDermott (2002, Ch. 5)

${ }^{7}$ According to data from the Polish and Czech National Statistical Offices, for Nace 29, Machinery and Equipment, real production increased from 1995 to 2000 by 5.92\% in the Czech Republic and 19.1\% in Poland, while by 1999

SMEs accounted for $35.97 \%$ of sectoral employment in the Czech Republic and $41.59 \%$ in Poland.

${ }^{8}$ This figure is generated from total non-bank privatization revenues through the direct and indirect paths of privatization. See Jarosz, p. 35, Table 4 (1999).

${ }^{9}$ In 1990, there were 8441 state enterprises. By December 1996, 5592 firms had entered a track of ownership transformation. There were two major systematic studies of 200 of these firms (across industries and regions) in 1995 and 1998 (Jarosz, 1996, 1999; Kozarzewski and Woodward 2000)

${ }^{10}$ I draw here mainly on the works of Gray and Holle (1998b), Dornisch (1997, 2000), and Montes-Negret and Papi (1996) as well as oninterviews in February 2002 with participants in EBRP from the Ministry of Finance, National Bank of Poland, and former executives of the bank in Lodz.

${ }^{11}$ For instance, the number of Czech municipalities grew by $50 \%$ by 1991 to 6237 with an average size of 1700 inhabitants, while Polish gminas maintained most of there integrity (2466 gminas with average size of 15, 000 inhabitants). For analysis of the political, resource, and financial differences, OECD (2000), Baldersheim, Illner, Offerdal, Rose, and Swianiewicz (1996), Gorzelak (1998), Levitas (1999), and Innes (2002). 


\section{DAVIDSON INSTITUTE WORKING PAPER SERIES - Most Recent Papers}

The entire Working Paper Series may be downloaded free of charge at: www.wdi.bus.umich.edu

CURRENT AS OF 6/30/03

\begin{tabular}{|c|c|c|}
\hline Publication & Authors & Date \\
\hline $\begin{array}{l}\text { No. 590: Institutional Change and Firm Creation in East-Central } \\
\text { Europe: An Embedded Politics Approach }\end{array}$ & Gerald A. McDermott & June 2003 \\
\hline $\begin{array}{l}\text { No. 589: Legitimacy, Interest Group Pressure and Institutional Change: } \\
\text { The Case of Foreign Investment and Host Country Governments }\end{array}$ & $\begin{array}{l}\text { Witold J. Henisz and Bennet A. } \\
\text { Zelner }\end{array}$ & June 2003 \\
\hline $\begin{array}{l}\text { No. 588: Institutions and the Vicious Circle of Distrust in the Russian } \\
\text { Household Deposit Market, 1992-1999 }\end{array}$ & Andrew Spicer and William Pyle & June 2003 \\
\hline $\begin{array}{l}\text { No. 587: Foreign Direct Investment and the Business Environment in } \\
\text { Developing Countries: the Impact of Bilateral Investment Treaties }\end{array}$ & $\begin{array}{l}\text { Jennifer Tobin and Susan Rose- } \\
\text { Ackerman }\end{array}$ & June 2003 \\
\hline No. 586: Trust in China: A Cross-Regional Analysis & Rongzhu Ke and Weiying Zhang & June 2003 \\
\hline No. 585: Family Control and the Rent-Seeking Society & $\begin{array}{l}\text { Randall Morck and Bernard } \\
\text { Yeung }\end{array}$ & June 2003 \\
\hline $\begin{array}{l}\text { No. 584: Wage Determination: Privatised, New Private and State } \\
\text { Owned Companies, Empirical Evidence from Panel Data }\end{array}$ & $\begin{array}{l}\text { Tomasz Mickiewicz and Kate } \\
\text { Bishop }\end{array}$ & June 2003 \\
\hline No. 583: An Investigation of Firm-Level R\&D Capabilities in East Asia & $\begin{array}{l}\text { Gary H. Jefferson and Zhong } \\
\text { Kaifeng }\end{array}$ & June 2003 \\
\hline $\begin{array}{l}\text { No. 582: R\&D and Technology Transfer: Firm Level Evidence From } \\
\text { Chinese Industry }\end{array}$ & $\begin{array}{l}\text { Albert G.Z. Hu, Gary H. } \\
\text { Jefferson, Guan Xiaojing and } \\
\text { Qian Jinchang }\end{array}$ & June 2003 \\
\hline $\begin{array}{l}\text { No. 581: Credit Market Disequilibrium in Poland: Can We Find } \\
\text { What We Expect? Non-Stationarity and the "Min", } \\
\text { Condition }\end{array}$ & $\begin{array}{l}\text { Christophe Hurlin } † \text { and Rafal } \\
\text { Kierzenkowski }\end{array}$ & June 2003 \\
\hline $\begin{array}{l}\text { No. 580: Does it Take a Lula to go to Davos? } \\
\text { A Brief Overview of Brazilian Reforms, 1980-2000 }\end{array}$ & $\begin{array}{l}\text { Nauro F. Campos, Armando } \\
\text { Castellar Pinheiro, Fabio } \\
\text { Giambiagi and Maurício M. } \\
\text { Moreira }\end{array}$ & June 2003 \\
\hline $\begin{array}{l}\text { No. 579: Ceaseless Toil? Health and Labor Supply of the Elderly in } \\
\text { Rural China }\end{array}$ & $\begin{array}{l}\text { Dwayne Benjamin, Loren Brandt } \\
\text { and Jia-Zhueng Fan }\end{array}$ & June 2003 \\
\hline $\begin{array}{l}\text { No. 578: Shadow Economy, Rent-Seeking Activities and the Perils of } \\
\text { Reinforcement of the Rule of Law }\end{array}$ & Ekaterina Vostroknutova & June 2003 \\
\hline $\begin{array}{l}\text { No. 577: No Pain, No Gain: Market Reform, Unemployment, and } \\
\text { Politics in Bulgaria }\end{array}$ & Neven Valev & June 2003 \\
\hline $\begin{array}{l}\text { No. 576: Power Analysis of the Nice Treaty On the Future of European } \\
\text { Integration }\end{array}$ & Yener Kandogan & June 2003 \\
\hline $\begin{array}{l}\text { No. 575: Democracy’s Spread: Elections and Sovereign Debt in } \\
\text { Developing Countries }\end{array}$ & $\begin{array}{l}\text { Steven A. Block, Burkhard N. } \\
\text { Schrage, and Paul M. Vaaler }\end{array}$ & June 2003 \\
\hline $\begin{array}{l}\text { No. 574: Reintroducing Intergenerational Equilibrium: Key Concepts } \\
\text { Behind the New Polish Pension System }\end{array}$ & Marek Góra & June 2003 \\
\hline $\begin{array}{l}\text { No. 573: Why Does FDI Go Where It Goes? New Evidence From the } \\
\text { Transition Economies }\end{array}$ & $\begin{array}{l}\text { Yuko Kinoshita and Nauro F. } \\
\text { Campos }\end{array}$ & June 2003 \\
\hline $\begin{array}{l}\text { No. 572: Private Savings in Transition Economies: Are There Terms of } \\
\text { Trade Shocks? }\end{array}$ & Abdur R. Chowdhury & May 2003 \\
\hline $\begin{array}{l}\text { No. 571: On the long-run determinants of real exchange rates for } \\
\text { developing countries: Evidence from Africa, Latin America and Asia }\end{array}$ & Imed Drine and Christophe Rault & May 2003 \\
\hline $\begin{array}{l}\text { No. 570: A re-examination of the Purchasing Power Parity using non- } \\
\text { stationary dynamic panel methods: a comparative approach for } \\
\text { developing and developed countries }\end{array}$ & Imed Drine and Christophe Rault & May 2003 \\
\hline $\begin{array}{l}\text { No. 569: How Important is Ownership in a Market with Level Playing } \\
\text { Field? The Indian Banking Sector Revisited }\end{array}$ & $\begin{array}{l}\text { Sumon Kumar Bhaumik and } \\
\text { Ralitza Dimova }\end{array}$ & May 2003 \\
\hline $\begin{array}{l}\text { No. 568: On Types of Trade, Adjustment of Labor and Welfare Gains } \\
\text { During Asymmetric Liberalizations }\end{array}$ & Yener Kandogan & May 2003 \\
\hline $\begin{array}{l}\text { No. 567: Technological Progress Through Trade Liberalization in } \\
\text { Transition Countries }\end{array}$ & Yener Kandogan & May 2003 \\
\hline
\end{tabular}

